\title{
Dietary guidelines for the Spanish population
}

\author{
Javier Aranceta ${ }^{1,2, *}$ and Lluís Serra-Majem ${ }^{3,4}$, on behalf of the Working Party for the \\ Development of Food-Based Dietary Guidelines for the Spanish Population $\dagger$ \\ ${ }^{1}$ Community Nutrition Unit, Bilbao Department of Public Health, Luis Briñas 18, 4th Floor, E-48013 Bilbao, Spain: \\ ${ }^{2}$ Associated Professor of Public Health and Community Nutrition, Comunitaria, Human Nutrition and Dietetics, \\ University of Navarra, Navarra, Spain: ${ }^{3}$ Professor of Preventive Medicine and Public Health, Director of the \\ Department of Clinical Sciences, University of Las Palmas de Gran Canaria, Las Palmas, Spain: ${ }^{4}$ Director of the \\ Research Group in Community Nutrition, Scientific Park of the University of Barcelona, Barcelona, Spain
}

\begin{abstract}
Therapeutic properties have been attributed to the diet since ancient times. Epidemiological evidence starting in the early 1960s supports the relationship between different dietary components, dietary balance and the development of risk factors for prevalent chronic diseases in Western societies. There is also evidence supporting the protective effect of other components of the diet and lifestyle, like regular physical activity.

During the last two years, groups of Spanish experts in the field of food, nutrition and health sciences have been involved in the process of analysing each food group in Spanish food patterns under a standard format. For each food group, current level of consumption, trends and scientific evidence linking each particular group or its components with patterns of disease, risk factors or protective effects have been determined from a public health perspective.

Conclusions and recommendations for each food group, agreed under consensus by the Spanish Society of Community Nutrition (SENC) collaborative group of experts, are summarised and reflected in the Food Guide Pyramid presented in this paper.
\end{abstract}

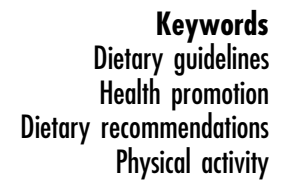

The potential contribution of diet to health and disease has been empirically recognised since ancient times ${ }^{1}$. During the first half of the twentieth century, nutrition and public health scientists focused their interest on providing adequate food and nutrient supply for all the population to satisfy energy and nutrient requirements ${ }^{1}$; thus to prevent nutrient deficiencies and disease related to them.

Epidemiological research carried out during the $1960 \mathrm{~s}$ and 1970s contributed to form the body of evidence linking diet and coronary heart disease. Later research has built on this substantially; current evidence supports the key role of diet in the development of chronic diseases. Furthermore, epidemiological and scientific evidence supports the role of diet and physical activity in the prevention of chronic diseases, major causes of mortality and morbidity in developed countries, to reduce the burden of disease $\mathrm{e}^{2,3}$. Obviously, this has led to changes in nutrition and public health policies, highlighting the

†SENC (Spanish Society of Community Nutrition). Working Party for the Development of Food-Based Dietary Guidelines for the Spanish Population: Javier Aranceta Bartrina (Editor), Lluis Serra-Majem, José Mataix Verdú (Co-ordinators), Carmen Pérez Rodrigo (Secretary), Pilar Cervera Ral, Rosaura Farré Rovira, Angel Gil, Remedios Guillén Sans, Consuelo López Nomdedeu, Florencio Marzo, Laura Monje Pardo, Rosa M Ortega, Fernando Rodríguez Artalejo, Jordi SalasSalvadó, Ramón Segura and Gregorio Varela Moreiras. relevance of both quantitative and qualitative aspects of usual dietary patterns ${ }^{4-8}$.

Nutritional Objectives and Food-Based Dietary Guidelines are useful strategies in the context of public health nutrition to effective develop action plans and national nutrition policies.

Food-based dietary guidelines are useful to translate messages conducive to achieve healthy dietary changes at population level ${ }^{6}$. The Declaration and Action Plan issued by the Food and Agriculture Organisation (FAO) during the International Conference for Nutrition in 1992 highlighted the importance of developing food-based dietary guidelines?.

Dietary guidelines must be based on solid scientific and epidemiological evidence relating different dietary patterns, risk factors or protective elements, considering the role of nutrients, non-nutrient compounds and the whole diet in order to achieve an 'optimal intake'10,11.

\section{Dietary guidelines for the Spanish population: overall structure}

The process for developing the new edition of Dietary Guidelines for the Spanish Population started in 1999 


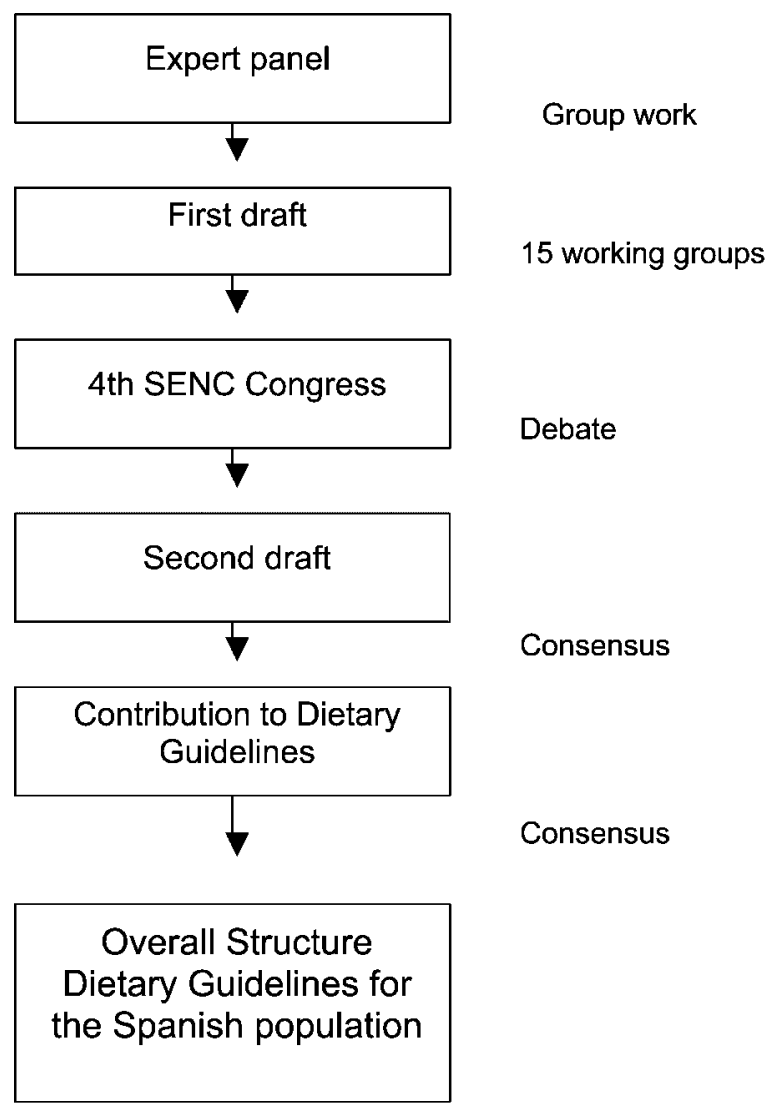

Fig. 1 Process followed in the preparation of the Food-Based Dietary Guidelines for the Spanish Population (SENC, 2001)

(Fig. 1). Expert groups in the field of health sciences, scientific societies and other relevant bodies from all over the country were involved. Each task force analysed a food group, in parallel, under a similar structure: food composition and nutritional value, cultural and anthropological aspects, socio-economic relevance, consumption trends for the whole food group and selected food items in the group, usual preparations and their impact on nutrient losses, current consumption, scientific evidence supporting each particular food group and the development of risk factors, protective effects, potential negative impact or safety hazards. Finally, on the basis of current consumption levels, recommendations to achieve desired levels were formulated. Additional remarks for population groups and special conditions have been included as well. Table 1 shows 'The Bilbao Declaration (2000): Ten Steps for a Healthy Diet'. This is a summary of the draft proposal suggested by the scientific committee of the 4th Congress of the Spanish Society of Community Nutrition, to be discussed as a basis for the new edition of the Dietary Guidelines for the Spanish Population ${ }^{12}$.

\section{Recommendations by food groups}

\section{Meat and meat products}

In adequate amounts, meat and meat products are an excellent source of essential amino acids, iron, zinc and B vitamins. Moderate consumption is advised, using alternatively other protein sources in the diet as well. Choose lean cuts with lower fat content; limit cuts and meat products with high content in saturated fats and sodium.

Meat and meat products are an important source of saturated fats, cholesterol, phosphorus and sodium in current Spanish food patterns. These commodities contribute also to high protein intake, well above recommended levels.

\section{Fish}

Fish is a good source of protein, iodine, and some varieties of $n-3$ fatty acids too; thus it should be part of the diet as an alternative to meat. Preferably, fish should be prepared with limited added fats; when offered to

Table 1 Ten Recommendations for a Healthy Diet: The Bilbao Declaration (2000)

Scientific evidence supports the fact that diet is an important factor for health at both the individual and population levels. In the context of Public Health, food is undoubtedly the best tool for health promotion. We must bear in mind that food habits are a cultural and social fact with a secular trend for adaptation to the environment from an anthropological as well as from a health perspective.

Within this framework, the Scientific Committee of the 4th SENC Congress - 3rd International Workshop of Community Nutrition, co-sponsored by WHO, highlights the following aspects as elements conducive to a healthy diet:

1. To adjust energy intake to energy output in order to achieve an energy balance conducive to maintain body mass index (BMI) within the desirable range.

2. To harmonise the percentage contribution of macronutrients to energy intake.

3. To achieve a healthier lipid profile in the diet by enhancing a relevant contribution of monounsaturated fatty acids (MUFAs), mostly from olive oil.

4. To stimulate changes in carbohydrate profile, through a higher proportion of complex carbohydrates.

5. To adjust daily frequency of consumption of sugary foods to less than 4 occasions per day.

6. A daily consumption of vegetables equal to or greater than $250 \mathrm{~g}$ is recommended, including at least one portion as fresh raw vegetables in a salad. A consumption of $400 \mathrm{~g}$ or more of fruit per person per day is also recommended.

7. Moderation in the consumption of alcoholic beverages is advised, within the Mediterranean consumption pattern, i.e. small amounts of wine with meals.

8. Introducing moderate physical exercise for at least 30 minutes within daily practices is highly recommended.

9. It would be advisable that public administrations and institutions stimulate, support and implement programmes aimed at developing individual skills contributing to food choices and preparations conducive to a healthy food pattern. Actions targeted to socially deprived environments should be a priority.

10. The need to draw global strategies to protect and recover traditional cooking styles is also noticed (gastronomic heritage) as a source of cultural and health wellness. 
children and elderly people, choose preparations avoiding bones.

\section{Eggs}

Eggs are a convenience food for all ages. Up to 3 or 4 eggs per week can be an alternative to meat and fish. Egg yolk is rich in cholesterol. This should be remembered when trying to avoid too much fat or too much cholesterol in the diet.

\section{Milk and dairy products}

Milk products provide high-quality protein, lactose, vitamins and calcium. However, milk and dairy products are an important source of fat, particularly saturated fats, in current Spanish food patterns. It is recommended to include 2-4 servings of milk and dairy products daily according to age and physiological condition. Under normal circumstances, usual consumption of low-fat products is not recommended for young children. Otherwise, it is advisable to choose low-fat dairy products.

\section{Legumes}

Legumes supply starch, dietary fibre and linoleic acid. Beans, peas, chicken peas, broad beans and lentils are good sources of protein. It is advisable to include 2 or more servings of legumes weekly in the diet, using preparations suitable to physiological conditions and personal preferences.

\section{Cereals and potatoes}

Cereals and potatoes should be the basis of everyday diet. Whole grains are rich in fibre, vitamins and minerals. However, consumers prefer refined cereals, thus the possibility of cereal fortification can be considered ${ }^{6}$. It would be advisable to include 4-6 servings daily of food items from this group. Consumption of buns and pastry should be moderated because of their fat content. Introduction of whole-grain cereals and whole-grain bread is recommended.

\section{Vegetables}

This food group is a good source of vitamins, minerals, fibre, antioxidants and phytochemicals. Consumption of 2 or more servings of vegetables daily is recommended, preferably including one serving as raw vegetables. This should account for $250 \mathrm{~g} \mathrm{person}^{-1} \mathrm{day}^{-1}$ as an intermediate objective, towards the desirable level of $300 \mathrm{~g}$ person $^{-1}$ day $^{-1}$.

\section{Fruit}

Effects of protective factors in fruits and vegetables are complex, since interactions enhance their effects, thus contributing to a greater biological potential. A variety of fruits should be included in the diet. Preparation and preservation methods affect their nutrient value to varying extents. From a health promotion perspective, considering the nutritional value and protective effects of this food group (on average better accepted than vegetables in this country), it is advisable to include 3 or more servings of fruit in the daily diet. This value is equivalent to the upper quartile for fruit consumption distribution in epidemiological studies showing a protective effect for this group ${ }^{4,13}$.

\section{Nuts}

Nuts are energy-dense foods (5.3 to $6.6 \mathrm{kcal} \mathrm{g}^{-1}$ ) on account of their poor hydration and high fat content. Saturated fats are low, while unsaturated fatty acids account for approximately 91\%. They are rich in fibre as well, particularly insoluble fibre. In general, the contribution of nuts to nutritional intake is limited since they are consumed just occasionally. However, this food group is an alternative source of plant-origin protein and fat.

\section{Fats and oils}

A limited consumption of animal fats from meat, meat products, dairy products, pastry, etc. is advised. There is evidence for the negative impact of trans-fatty acids and vegetable oils rich in saturated fats on plasma lipid profile.

Consumption of lean meats and plant oils, especially olive oil, is recommended, overall moderating fat intake. Avoid too much fat.

\section{Sugar, sugary foods and beverages}

High consumption of sugar can negatively affect health by increasing the risk for dental caries, obesity, etc.

Different sources of carbohydrate should supply at least $55 \%$ daily energy intake, provided most of them are low glycaemic index polysaccharides. Whenever energy intake is well above desired levels, sugar intake which might compromise micronutrient density in the diet - should be moderated, while increasing complex carbohydrates, particularly those from whole-grain cereals. Sugary foods should be limited to fewer than 4 occasions daily (occasional consumption is recommended).

\section{Water}

The nutritional value of water depends on its mineral content. Mineral waters differ from one another in their mineral composition, which influences their positive healthy properties. Consumption of coffee and tea in Spain has remained stable in recent years, while that of bottled waters has doubled. Providing adequate liquid intake is mandatory (as water, tea, etc.) in variable amounts depending on factors such as age and physiological condition. Special care should be paid to children and the aged.

\section{Alcobolic beverages}

Alcobol abstinence is recommended for: children, pregnant and breast-feeding women, people with high intake 
unable to moderate, people with alcohol dependence, ill people for whom alcohol worsens their health, people taking pharmaceutical drugs, everyone while at work or driving.

Alcohol consumption is not recommended for: people who do not like it and people younger than 50 years old with low cardiovascular risk.

Grape juice and fresh grapes are a good source of polyphenols, resveratrol and other phytochemicals with equivalent biological potential to other food sources. Non-alcoholic beer and other non-alcoholic drinks can be an alternative option.

General recommendation is the least alcohol, the best for your health. Consumption of alcohol can be acceptable for people older than 50 years with several cardiovascular risk factors, who enjoy moderate amounts of alcoholic drinks with meals (moderate consumption is not more than two glasses of wine a day or equivalent amounts of other fermented beverages).

\section{Physical activity and body weight}

Energy intake should be aimed to satisfy nutritional requirements and contribute to energy balance, i.e. maintain a healthy body weight. Planning daily diet should include an individual plan for physical activity as well: moderate, enjoyable and on a continuing basis. Expert advice from a family physician or a physiotherapist would be valuable for planning the most suitable type and intensity of physical exercise according to personal characteristics and health condition, appropriate recommendations and cautions. A minimum standard would be a 30-40 minutes' walk daily.

\section{Breast-feeding}

Breast-milk is the best food for the newborn. There is a body of evidence supporting the favourable aspects of breast-feeding both for the mother and the child, from a physiological and a psychological point of view, not only during the first months of life, but as a protective factor in later stages.

The recommendation is to encourage breast-feeding for at least 4 months, desirably for 6 months as mid-term objective.

\section{Diet variety}

Diet variety - i.e. including food items from all of the basic food groups - is the connection among all the above recommendations. By following this advice, the usual food pattern will consist of a variety of food groups in the proportions suggested in the Spanish Food Guide Pyramid for a Healthy Diet. This will supply enough calories according to physical activity levels, with moderate fat content mostly from olive oil, and adequate nutrient density for water, fibre, vitamins and minerals. This food typology will contribute to achieve and maintain Nutritional Objectives for the Spanish population ${ }^{14}$.

In the near future, priorities in community nutrition action will focus on providing safe food to the public,

\section{Food Guide Pyramid}

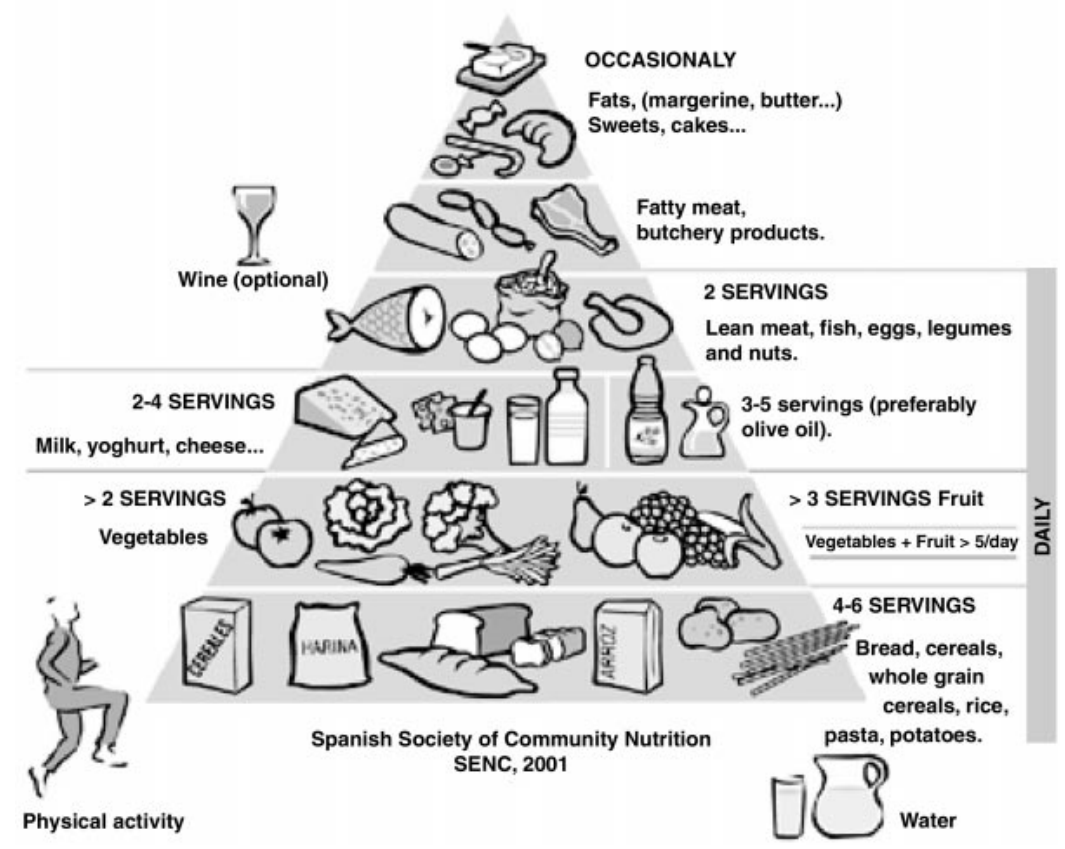

Fig. 2 Spanish Food Guide Pyramid (SENC, 2001) 
Table 2 The Spanish Food Guide Pyramid

\begin{tabular}{|c|c|c|c|c|}
\hline $\begin{array}{l}\text { Frequency } \\
\text { category }\end{array}$ & Foods included in each level & $\begin{array}{l}\text { Recommended } \\
\text { frequency } \\
\text { of consumption }\end{array}$ & $\begin{array}{l}\text { Portion size } \\
\text { (net raw weight) }\end{array}$ & Household measures \\
\hline \multirow{11}{*}{$\begin{array}{l}\text { DAILY } \\
\text { CONSUMPTION }\end{array}$} & First level (Pyramid base): & & & \\
\hline & $\begin{array}{l}\text { Potatoes, rice, bread, whole-grain bread, pasta, } \\
\text { a variety of flours and cereals }\end{array}$ & $\begin{array}{l}4-6 \text { servings } \\
\text { per day }\end{array}$ & $\begin{array}{l}60-80 \mathrm{~g} \text { pasta, rice } \\
40-60 \mathrm{~g} \text { bread } \\
150-200 \mathrm{~g} \text { potatoes }\end{array}$ & $\begin{array}{l}1 \text { average plate } \\
3-4 \text { slices or a roll } \\
1 \text { big potato or } 2 \\
\text { small ones }\end{array}$ \\
\hline & Water & $\begin{array}{l}4-8 \text { servings } \\
\text { per day }\end{array}$ & $200 \mathrm{ml}$ approx. & 1 glass or 1 small bottle \\
\hline & Second level: & & & \\
\hline & $\begin{array}{l}\text { Vegetables are located on the left side (lettuce, } \\
\text { tomatoes, carrots, cauliflower, leeks, onions, etc.) }\end{array}$ & $\begin{array}{l}\geq 2 \text { servings } \\
\text { per day }\end{array}$ & $150-200 \mathrm{~g}$ & $\begin{array}{l}1 \text { plate of assorted salad } \\
1 \text { plate of cooked } \\
\text { vegetables } \\
1 \text { big tomato, } 2 \text { carrots } \\
\text { Side dishes can account } \\
\text { for } 1 / 2 \text { serving }\end{array}$ \\
\hline & $\begin{array}{l}\text { Fruits are located on the right side (oranges, } \\
\text { apples, pears, grapes, strawberries, etc.) }\end{array}$ & $\begin{array}{l}\geq 3 \text { servings } \\
\text { per day }\end{array}$ & $120-200 \mathrm{~g}$ & $\begin{array}{l}1 \text { medium piece } / 1 \text { cup } \\
\text { of cherries, strawberries, } \\
\text { etc. } / 2 \text { slices of melon }\end{array}$ \\
\hline & Third level (upper level): & & & \\
\hline & $\begin{array}{l}\text { Milk, dairy products, such as yoghurt, cheese, } \\
\text { fresh cheese, cottage cheese, etc. }\end{array}$ & $\begin{array}{l}2-4 \text { servings } \\
\text { per day }\end{array}$ & $\begin{array}{l}200-250 \mathrm{ml} \text { milk } \\
200-250 \mathrm{~g} \text { yoghurt } \\
40-60 \mathrm{~g} \text { mature } \\
\text { cheese }\end{array}$ & $\begin{array}{l}1 \text { cup of milk } \\
2 \text { units of yoghurt } \\
2-3 \text { slices of cheese }\end{array}$ \\
\hline & & & $\begin{array}{l}125 \mathrm{~g} \text { of fresh } \\
\text { cheese }\end{array}$ & 1 individual portion \\
\hline & Olive oil & $\begin{array}{l}3-5 \text { servings } \\
\text { per day }\end{array}$ & $10 \mathrm{ml}$ & 1 spoonful \\
\hline & $\begin{array}{l}\text { Encouraging to practice daily physical activity } \\
\text { Fourth level (upper level): }\end{array}$ & Daily & $\geq 30$ minutes & \\
\hline \multirow[t]{4}{*}{$\begin{array}{l}\text { WEEKLY } \\
\text { CONSUMPTION }\end{array}$} & Fish & $\begin{array}{l}\text { Alternate between } \\
\text { them }\end{array}$ & $\begin{array}{l}125-150 \mathrm{~g} \\
\text { (net weight) }\end{array}$ & $\begin{array}{l}1 \text { individual fillet } \\
2-3 \text { slices of fish }\end{array}$ \\
\hline & Lean meat, poultry and eggs & & & $\begin{array}{l}1 \text { small fillet, } 1 \text { chicken } \\
\text { leg, } 1 / 4 \text { rabbit, } 1-2 \text { eggs }\end{array}$ \\
\hline & Legumes (beans, chick peas, lentils, soy, etc.) & $\begin{array}{l}2-3 \text { servings } \\
\text { weekly of } \\
\text { legumes }\end{array}$ & $60-80 \mathrm{~g}$ & $\begin{array}{l}1 \text { individual plate } \\
\text { (150-200 g cooked } \\
\text { weight) }\end{array}$ \\
\hline & Nuts & & $20-30 \mathrm{~g}$ & $\begin{array}{l}1 \text { handful or individual } \\
\text { pack }\end{array}$ \\
\hline \multirow[t]{3}{*}{$\begin{array}{l}\text { OCCASIONAL } \\
\text { CONSUMPTION }\end{array}$} & $\begin{array}{l}\text { Fifth level: Butchery products (chorizo, morcilla, } \\
\text { etc.) and fatty meats }\end{array}$ & Occasionally & - & Moderate \\
\hline & $\begin{array}{l}\text { Sixth level: Sweets, cakes, sugary or salted } \\
\text { snacks, sugary soft drinks }\end{array}$ & $\begin{array}{l}<4 \text { occasions } \\
\text { per day } \\
\text { Occasionally }\end{array}$ & - & Moderate \\
\hline & $\begin{array}{l}\text { Seventh level: Butter, margarine, manufactured } \\
\text { cakes, buns }\end{array}$ & Occasionally & - & Moderate \\
\hline
\end{tabular}

monitoring implementation of Dietary Guidelines in all fields (including commercial and social catering services) and wider consideration given to dietary counselling, particularly in primary health care and out-patient followup. Food policies should encourage social support to vulnerable groups, disadvantaged people and subgroups that are excluded socially.

\section{The Spanish Food Guide Pyramid}

Based on the recommendations above, dietary guidelines for the Spanish population are summarised graphically in a pyramid model with the structure described below (Fig. 2). Food items in the base should provide the highest proportion of energy intake; thus daily consumption of these foods in the amounts suggested is encouraged for a healthy diet. Immediate upper levels towards the top indicate progressively decreasing frequency of consumption and contribution to energy intake, from daily to weekly consumption, up to those in the vertex recommended to be in the diet occasionally (Table 2).

No single food in itself can be considered good or bad for health. It is the frequency and the proportion of foods present in the usual diet and their contribution to nutrient intake that make a dietary pattern healthy or unhealthy.

These recommendations are complemented with an invitation to be physically active, by practising daily moderate physical exercise and balancing energy intake to physical activity in order to maintain a healthy body weight.

Finally, water should be provided in variable amounts according to age and personal condition. Optionally, 
moderate amounts of wine can be present in the diet or equivalent amounts of grape juice as a non-alcoholic alternative choice.

\section{References}

1 Harper AE. Myth and magic nutrition. In: Leathwood P, Horisberger M, James WPTeds. For a Better Nutrition in the 21st Century. Nestlé Nutrition Workshop Series, Vol. 27. New York: Raven Press, 1993; 15-30.

2 Organización Mundial de la Salud (OMS), Comité de expertos. Dieta, Nutrición y Prevención de Enfermedades Crónicas. Serie Informes Técnicos No. 797, Ginebra: OMS, 1990.

3 National Research Council. Diet and Health. Implications for Reducing Chronic Disease Risk. Washington, DC: National Academy Press, 1989.

4 Expert panel, World Cancer Research Fund/American Institute for Cancer Research (WCRF/AICR). Food, Nutrition and the Prevention of Cancer: A Global Perspective. Washington, DC: WCRF/AICR, 1997.

5 Ferro-Luzzi A, James WPT. Diet and health: brief summary of our present knowledge and description of the present European situation in terms of diet, health and their relationship. In: Trichopoulou A, ed. Nutrition in Europe. Final Report. Luxembourg: STOA, European Parliament, Directorate for General Research, 1997; 2-38.

6 Serra Majem Ll, Aranceta Bartrina J. Guías alimentarias, educación nutricional, fortificación y suplementación. In: Gálvez Vargas R, Sierra López A, Sáenz González MC, Gómez López LI, Fernández-Crehuet Navajas J, Salleras
Sanmartí L, et al. eds. Piédrola Gil Medicina Preventiva y Salud Pública, 10th ed. Barcelona: Masson, 2001; 923-34.

7 United States Department of Agriculture-United States Department of Health and Human Services (USDAUSDHHS). Nutrition and Your Health. Dietary Guidelines for Americans, 5th ed. Washington, DC: USDA-USDHHS, 2000.

8 Kafatos A, Codrington C, eds. Eurodiet Reports and Proceedings [special issue]. Public Health Nutr. 2001; 4(2A): 265-436.

9 Food and Agriculture Organisation/World Health Organisation (FAO/WHO). Preparation and Use of Food-Based Dietary Guidelines. Report of a joint FAO/WHO consultation. WHO Technical Report Series 880, Geneva: WHO, 1998.

10 Margetts B, Warm D, Yngve A, Sjostrom M. Developing an evidence-based approach to Public Health Nutrition: translating evidence into policy. Public Health Nutr. 2001; 4: $1393-7$.

11 Aranceta Bartrina J. Objetivos nutricionales y Guías Dietéticas. In: Nutrición Comunitaria, 2nd ed. Barcelona: Masson, 2001; 175-90.

12 Aranceta J, Pérez-Rodrigo C, Serra-Majem Ll, Mataix J. An update in community nutrition: Fourth Congress of the Spanish Society of Community Nutrition (SENC) and the Third International Workshop of Community Nutrition. $B r$. Nutr. Found. Nutr. Bull. 2001; 26: 21-3.

13 WHO Europe. CINDI Dietary Guide. Copenhague: World Health Organisation, 2000.

14 Serra-Majem Ll, Aranceta J, SENC Working Group on Nutritional Objectives for the Spanish Population. Nutritional objectives for the Spanish population. Consensus from the Spanish Society of Community Nutrition. Public Health Nutr. 2001; 4: 1409-13. 